\title{
Petrogenesis of Girnar volcano- plutonic complex in Deccan Traps, India
}

\author{
MAHESH HALDER ${ }^{1 *}$, DEBAJYOTI PAUL ${ }^{2}$, \\ ANDREAS STRACKE ${ }^{3}$
}

${ }^{1}$ Department of Earth Sciences, Indian Institute of Technology, Kanpur 208016, India

(*correspondence: maheshh@iitk.ac.in)

${ }^{2}$ Department of Earth Sciences, Indian Institute of Technology, Kanpur 208016, India (e-mail: dpaul@iitk.ac.in)

${ }^{3}$ Westfälische Wilhelms-Universität, Institut für Mineralogie,

Münster, Germany (e-mail: astra_01@uni-muenster.de)

The Girnar Hill Complex within the Deccan Traps, India is a volcano-plutonic complex consisting of various mafic to silicic rocks. Diorite is the main rock type, forming a central hill ( $\sim 1100 \mathrm{~m})$, which is surrounded by gabbro, and low-lying basaltic flows; syenite veins occur within diorite. Silicic rocks occur as semi-circular hills at the outer margin and enclose the entire complex. Diopside and augite are the dominant phases in gabbro and diorite, whereas (shattered) pigeonite is present in the coarse-grained silicic rocks. A prominent silica gap is observed between silicic rocks $\left(70-75 \mathrm{wt} \% \mathrm{SiO}_{2}\right)$ and mafic rocks $\left(<55 \mathrm{wt} \% \mathrm{SiO}_{2}\right)$. Chondrite-normalized rare earth elements (REEs) patterns for the basalt and gabbro show moderate relative LREE enrichments $\left(\mathrm{La} / \mathrm{Sm}_{\mathrm{N}} \sim 0.9-1.8\right)$, and a distinct positive Eu anomaly indicating accumulation of plagioclase. Diorite displays a flat HREE pattern $\left(\mathrm{Gd} / \mathrm{Lu}_{\mathrm{N}} \sim 2\right)$ similar to basalt and gabbro but more LREE enrichment $\left(\mathrm{La} / \mathrm{Sm}_{\mathrm{N}} \sim 5.6\right)$. Silicic rocks have highly enriched REE patterns $\left(\mathrm{La} / \mathrm{Sm}_{\mathrm{N}} \sim 3\right)$, a prominent negative $\mathrm{Eu}$ anomaly, suggesting fractional crystallization of plagioclase or partial melting in the plagioclase stability field. Sr-Nd-Hf isotopic composition of the mafic rocks $\left({ }^{87} \mathrm{Sr} /{ }^{86} \mathrm{Sr}=0.704-0.707\right.$, ${ }^{143} \mathrm{Nd} /{ }^{144} \mathrm{Nd}=0.512587-0.512733, \quad{ }^{176} \mathrm{Hf} /{ }^{177} \mathrm{Hf}=$ $0.282912-0.282962)$ indicate mantle origin with variable, but moderate crustal input. In contrast, silicic rocks $\left({ }^{87} \mathrm{Sr} /{ }^{86} \mathrm{Sr}=\right.$ $0.724-0.732,{ }^{143} \mathrm{Nd} /{ }^{144} \mathrm{Nd}=0.512237-0.512280,{ }^{176} \mathrm{Hf} /{ }^{177} \mathrm{Hf}$ $=0.282569-0.282599)$ are highly contaminated by incorporating different types of the local continental crust. Geochemical variations, particularly trace elements and isotopic ratios of rocks from the Girnar volcano-plutonic complex of Deccan Traps indicate an important role of continental crust in the generation of silicic rocks that are associated with Continental Flood Basalts. 